\title{
Kendala Implementasi Kebijakan Fasilitasi Alat Peraga Kampanye Pemilu 2019 di Kota Bukittinggi
}

Riki Rahmad*, Asrinaldi, Indraddin

rikirahmad@gmail.com, asrinaldi@soc.unand.ac.id,indrazainudin@yahoo.com

${ }^{1}$ Program Tata Kelola Pemilu, Fakultas Sosial dan Ilmu Politik, Universitas Andalas

${ }^{23}$ Fakultas Ilmu Sosial dan Ilmu Politik, Universitas Andalas

\begin{abstract}
Abstrak
Penelitian bertujuan menganalis faktor-faktor penghambat implementasi kebijakan fasilitasi Alat Peraga Kampanye (APK) di Kota Bukittinggi. Alat peraga kampanye berupa spanduk dan baliho pada tahun 2019 tidak dipasang pada zona yang telah ditentukan dan bahkan ada peserta pemilu yang tidak memanfaatkan fasilitasi APK dari KPU. Padahal dana pemerintah yang digunakan untuk kebijakan fasilitasi ini lumayan besar. Penelitian ini menggunakan penelitian kualitatif deskriptif dengan pendekatan studi kasus, prosedur pengumpulan data berupa wawancara, observasi dan dokumentasi. Teori yang dipakai adalah model implementasi kebijakan oleh Korten dan pendekatan efektifitas kebijakan. Model ini berfokus pada kesesuaian antara tiga elemen yaitu program, pelaksanaan, dan kelompok sasaran. Hasil penelitian menunjukkan bahwa peserta pemilu tidak memanfaatkan fasilitas APK disebabkan oleh; (1) Aturan KPU tentang ukuran, desain, dan konten APK tidak sesuai dengan persepsi kebutuhan persuasi peserta pemilu, (2) Partai politik menghindari konflik dengan caleg mengingat konten APK tidak mengakomodasi foto caleg, (3) Kendala biaya pemasangan dan pemeliharan APK oleh peserta pemilu. Ditinjaun dari efektifitasnya, kebijakan fasilitasi APK pada Pemilu tahun 2019 di Kota Bukittinggi belum mencapai tujuan. Tidak sejalannya sistem pemilu proporsional terbuka dengan kebijakan fasilitasi APK menyebabkan beberapa dampak dalam proses kampanye antara lain 1) persaingan antar caleg dalam berkampanye menjadi tidak kompetitif dan 2) fasilitasi APK yang diadakan oleh KPU sebagian besar tidak terpakai.
\end{abstract}

Kata kunci: Alat Peraga Kampanye, efektifitas, kebijakan, KPU, pemilu.

\begin{abstract}
This study aims to analyze the factors inhibiting the implementation policy of the Campaign Props (APK) in Bukittinggi City. APK in the form of banners and billboards in the 2019 election campaign, many APKs that have been facilitated by the Election Commition (KPU) are not installed in the designated zones and there are even election participants who do not utilize this APKs facilitation, even though the state funds used for this Facilities are quite large. This study uses descriptive qualitative research with a case study approach, data collection procedures in the form of interviews, observation and documentation. The theory used is the corten implementation model in which this Mode is based on the compatibility between the three elements that is program, implementation, and target group. The results showed that election participants did not utilize the APK facility caused by (1) KPU rules regarding the size, design, and content of APKs are not in accordance with the perception of the election participants' persuasion needs (2) Political parties avoid conflicts with candidates considering that the APK content does not accommodate candidates photos (3) costs for installing and maintaining APKs are none from election participants. Judging from its effectiveness APK's facilitation policy in the 2019 elections in Bukittinggi City has not reached its goal. Inconsistency with the open proportional electoral system with the APK facilitation policy has several impacts in the campaign process, among others 1) competition between candidates in campaigning becomes uncompetitive 2) most APK facilitation held by KPU is largely unused..
\end{abstract}

Keywords : campaign props, effectiveness, election, General Election Commission, policy.

\section{Pendahuluan}

Tahapan kampanye merupakan tahapan yang krusial dalam tahapan Pemilu, hal itu disebabkan karena kampanye selain melibatkan banyak massa dan dilakukan serentak secara

\footnotetext{
${ }^{*}$ Corresponding Author: Riki Rahmad, Jl. Abdul Manan No. 56, Bukittinggi, Sumatera Barat, Indonesia 26128
} 
nasional akan tetapi juga waktu yang diberikan cukup lama yaitu sekitar tujuh bulan. Pemilihan metode Kampanye yang efektif dan efisien merupakan hal yang penting dalam rangka meraih dukungan pemilih. Momen kampanye menjadi penting disebabkan pada momen tersebut partai politik dapat kembali meyakinkan massa pendukung (konstituen) untuk memilih partai dan calon yang akan diusung (Kurniawan, 2009). Akan tetapi, kehadiran alat peraga kampanye pada Pemilu pada masa lalu sudah terlalu banyak jumlahnya dan mengganggu keindahan. Bukannya dipandang sebagai alat pemberi informasi dari kandidat kepada pemilih tetapi membuat risih karena mengotori lingkungan (Yulianto, 2014).

Undang-undang No. 7 Tahun 2017 tentang Pemilihan umum telah mengatur khusus mengenai kampanye yaitu Pada Pasal 275 Ayat 2 bahwa KPU Memfasilitasi beberapa jenis metode kampanye, yaitu pemasangan Alat Peraga Kampanye (APK) di tempat umum, iklan kampanye pada media cetak, media massa elektronik, internet dan debat pasangan calon yang di danai oleh APBN (Pemerintah Indonesia, 2017). Tujuan utama dari fasilitasi tersebut sesuai dengan Peraturan KPU No. 23 Tahun 2018 Mengenai Kampanye Pemilihan Umum pasal 4 ayat 5 adalah peserta pemilu mempunyai hak, kesempatan, dan perlakuan yang adil dan setara dalam Kampanye (KPU, 2018). Kampanye dalam pemilu merupakan salah satu kekuatan politik yang sangat penting dalam sistem politik demokrasi. Kampanye sebagai instrumen atau sarana pendidikan politik masyarakat. Dalam konteks partai politik (parpol), kampanye politik merupakan serangkaian tindakan yang dilakukan terencana, yang diharapkan menciptakan efek tertentu pada sejumlah besar khalayak dan dilakukan secara berkelanjutan pada kurun waktu tertentu (Rogers \& Storey, 1987). Dengan demikian, KPU harus bersikap adil dan setara dalam hal kampanye bagi peserta pemilu dengan cara memberi ruang yang sama dalam menyampaikan visi-misi mereka.

Banyak pertentangan mengenai keterkaitan Alat peraga kampanye dengan tingkat partisipasi pemilih. Beberapa penelitian ada yang menyatakan bahwa peran Spanduk dan baliho tidak terlalu berpengaruh terhadap partisipasi pemilih apalagi dihubungkan dengan tingkat kepercayaan publik terhadap calon yang telah mereka pemilih pada Pemilu sebelumya. Akan tetapi, masih banyak juga penelitian yang menyatakan bahwa media kampanye luar ruangan masih efektif dipakai pada saat sekarang ini. Seperti Hasil survey yang dilakukan oleh Puskapol UI (2013) dalam hasil survey nasional tentang iklan politik dan perilaku pemilih menjelang Pemilu 2009 yang menyatakan bahwa mayoritas masyarakat mengatakan bahwa sumber informasi tentang partai politik dan caleg umumnya diperoleh melalui spanduk atau baliho (72\%). Penelitian berjudul 'Pengukuran efektifitas penggunaan media baliho pada pemilihan Umum 2019 terhadap generasi milenial' mengambil kesimpulan bahwa di era digital ini ternyata media konvensional masih menjadi alternatif dalam penyampaian informasi yang bersifat persuasif. Diketahui bahwa 62,5\% generasi milenial mengatakan penggunaan baliho oleh bakal calon legislatif dianggap sebagai upaya yang tepat dalam memberikan pesan politik kepada calon pemilih (Sutarini, 2019).

Fasilitasi alat peraga kampanye yang dilakukan oleh KPU memang bukanlah kebijakan yang baru, kebijakan tersebut sudah dimulai diterapkan KPU pada Pilkada tahun 2015. Untuk Pemilu Tahun 2019 ini KPU mengeluarkan Peraturan KPU No. 23 Tahun 2018 yang mengatur mengenai Kampanye Pemilu Tahun 2019. Fasilitasi yang dilakukan pada masa Pilkada 2015 dengan Pemilu 2019 tentu saja berbeda. Permasalahan fasilitasi APK yang terjadi pada tahap implementasi kebijakan tersebut adalah dari observasi yang telah penulis lakukan pada saat Pemilu tahun 2019 di 
Kota Bukittinggi selama masa kampanye yang dimulai dari tanggal 23 September 2018 sampai dengan 13 April 2019 masih banyak yang tidak terpasang. Mengapa itu bisa terjadi dan apa penyebabnya?

Fenomena ini perlu dilakukan kajian yang lebih mendalam karena dalam hal perumusan dan implementasi kebijakan publik akan selalu berkaitan aspek dengan politik seperti disebut oleh Surbakti (1992) dengan istilah fungsionalisme. Fungsionalisme memandang bahwa politik sebagai kegiatan formulasi dan implementasi kebijakan publik (Surbakti, 1992). Kebijakan publik dipelajari pada dasarnya agar pada setiap perundangan dan regulasi yang dihasilkan dapat tepat guna mencapai tujuan yang sesuai target. Dalam hubungan pertimbangan politis ini perlu dibedakan antara policy analysis dan policy advicary. Policy analysis pada dasarnya berhubungan dengan pengetahuan tentang sebab dan akibat yang timbul dari suatu kebijakan public (Dunn, 2003). Sedangkan, policy advocacy khususnya berhubungan dengan apa yang harus dikerjakan oleh pemerintah, dengan kemajuan kebijakan tertentu, melalui diskusi, pendekatan, dan aktifitas politik

Tahap Implementasi merupakan tahapan yang sangat penting dalam suatu kebijakan artinya implementasi merupakan tahap dimana suatu kebijakan dilaksanakan secara maksimal dan dapat mencapai tujuan kebijakan itu sendiri. Sebagaimana yang disampaikan oleh Sabatier \& Mazmanian (1980) yang menyatakan bahwa hakikat utama implementasi adalah memahami hal-hal yang seharusnya terjadi setelah suatu program dinyatakan berlaku atau dirumuskan, pemahaman itu mencakup usaha-usaha pengadministrasiannya dan menimbulkan dampak nyata dalam kehidupan masyarakat.

Beberapa Kajian yang dilakukan mengenai alat peraga kampanye seperti Penulisan yang dilakukan oleh Muchamad Yulianto yang berjudul "Evaluasi Alat Peraga Kampanye Pemilihan Umum di Era Demokrasi Elektoral“" (Yulianto, 2014) mendapati kesimpulan bahwa karena jumlahnya yang banyak, isi pesan dan tampilan alat peraga kampanye cenderung monoton. Lokasi pemasangan yang tidak beraturan juga menambah kesan negatif tentang alat peraga. Dalam tesis yang dilakukan oleh Ade Alifya yang berjudul "Evaluasi Kebijakan Public Funding Pada Kampanye Pemilihan Kepala Daerah di Sumatera Barat”, didapat kesimpulan bahwa kebijakan public funding pada kampanye pilkada serentak di Sumatera Barat tidak efektif. Ketidakefektifan ini disebabkan oleh ketidaksiapan pasangan calon dan tim kampanye dengan kebijakan ini sehingga masih mempertahan pola lama dalam melaksanakan kampanye.

Beberapa kajian diatas sangat menarik, namun pada umumnya lebih banyak mengkaji kepada aspek Kegiatan Pemilihan Kepala Daerah (Pilkada), masih belum ada yang membahas mengenai efektivitas dari Fasililitasi APK oleh KPU pada masa Pemilu 2019. Menarik juga dibahas mengenai bagaimana penerapan implementasi dari kebijakan Fasilitasi APK dari KPU itu sendiri, apakah implementasi dari kebijakan tersebut sudah sesuai dengan dua variabel besar tentang keberhasilan implementasi kebijakan yang dikemukakan oleh Korten dalam (Akib \& Tarigan, 2008) yang menyatakan bahwa suatu program akan berhasil dilaksanakan jika terdapat kesesuaian dari tiga unsur implementasi program. Pertama, kesesuaian antara program dengan pemanfaat. Kedua, kesesuaian antara program dengan organisasi pelaksana. Ketiga, kesesuaian antara syarat yang diputuskan organisasi untuk dapat memperoleh output program yang diinginkan.

Berdasarkan permasalahan diatas, penulisan ini menjawab permasalahan berikut. Pertama, Menganalis dan mengkaji implementasi kebijakan fasilitasi APK yang dilakukan oleh KPU Kota 
Bukittinggi bagi peserta Pemilu Tahun 2019. Kedua, megkaji bagaimana hubungan antara tidak maksimalnya fungsi fasilitasi APK yang dilakukan KPU dengan sistem Pemilu Proporsional terbuka. Oleh karena itu sudah semestinya dibahas dan evaluasi mendalam mengenai efektivitas implementasi kebijakan fasilitasi APK Pemilu 2019 oleh KPU sehingga nantinya diharapkan dapat menghasilkan Pemilu yang bekualitas dan berintegritas.

David C. Korten (1980) membuat Model Kesesuaian implementasi kebijakan atau program dengan memakai pendekatan proses pembelajaran. Pada gambar 1 dijelaskan bahwa model ini menaruh perhatian pada kesesuaian antara tiga elemen yang ada dalam pelaksanaan program, yaitu program itu sendiri, pelaksanaan program dan kelompok sasaran program. Korten menyatakan bahwa suatu program akan berhasil dilaksanakan jika terdapat kesesuaian dari tiga unsur implementasi program; 1) Kesesuaian antara program dengan pemanfaat, yaitu kesesuaian antara apa yang ditawarkan oleh program dengan apa yang dibutuhkan oleh kelompok sasaran (pemanfaat), 2) kesesuaian antara program dengan organisasi pelaksana, yaitu kesesuaian antara tugas yang disyaratkan oleh program dengan kemampuan organisasi pelaksana, dan 3) kesesuaian antara syarat yang diputuskan organisasi untuk dapat memperoleh output program dengan apa yang dapat dilakukan oleh kelompok sasaran program.

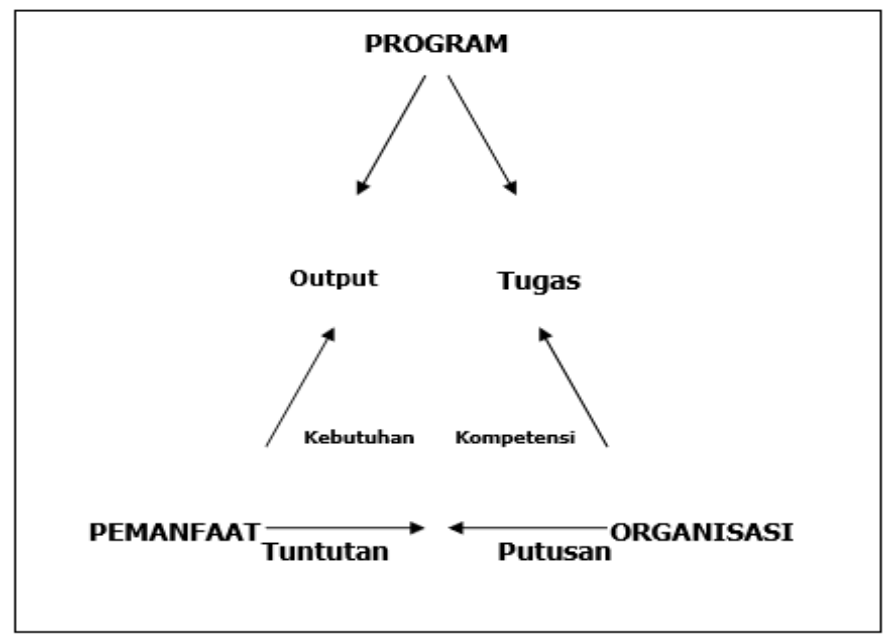

Gambar 1. Model Kesesuian David C. Korten (1980)

Dalam Penulisan ini penulis menggunakan model pengukuran kesuksesan implementasi dari model Korten dikarenakan selain model ini menggunakan sistem Top Down karena regulasi pengaturan alat peraga kampanye merupakan peraturan yang dibuat oleh KPU RI ditingkat pusat yang digunakan sampai dengan tingkat KPU Kabupaten/Kota, model ini juga memberikan rincian yang sangat mendalam terhadap konteks implementasi kebijakan dibandingkan dengan model lainnya, terutama yang bersangkutan dengan kesesuaian antara kebijakan Fasilitasi APK dengan pelaksanaan dilapangan. Model ini juga mengukur sejauh mana tingkat kepatuhan dari pelaksanaan kebijakan itu sendiri. Apabila dikaitkan dengan implementasi fasilitasi alat peraga kampanye pada Pemilu Tahun 2019 di Kota Bukittinggi yang mana tingkat kepatuhan dari peserta Pemilu dalam hal pemasangan alat peraga kampanye masih kurang. Selain itu melalui model ini diharapkan dapat menggambarkan sejauh mana kesuksesan implementasi dari program fasilitasi alat peraga kampanye tersebut. 
Alat Peraga Kampanye merupakan media yang digunakan oleh kandidat dan partai untuk mengkomunikasikan bagaimana pemilih memilih calon. Menurut Peraturan KPU No. 23 Tahun 2018 alat peraga kampanye adalah semua benda atau bentuk lain yang memuat visi, misi, program, dan/atau informasi lainnya dari Peserta Pemilu, simbol atau tanda gambar Peserta Pemilu, yang dipasang untuk keperluan Kampanye yang bertujuan untuk mengajak orang memilih Peserta Pemilu tertentu (KPU, 2018). Sesuai dengan penjelasan diatas KPU Pada Pemilu 2019 melakukan fasilitasi Alat Peraga Kampanye berupa spanduk dan baliho, untuk itu perlu untuk dilakukan kajian mengenai efektifitas program fasilitasi tersebut.

Efektivitas merupakan salah satu kriteria yang digunakan untuk melihat seberapa berhasilnya program yang telah dilaksanakan. Efektifitas Berkenaan dengan apakah suatu alternatif mencapai hasil (akibat) yang diharapkan, atau mencapai tujuan dari diadakannya tindakan. Efektifitas, yang secara dekat berhubungan dengan rasionalitas teknis, selalu diukur dari unit produk atau layanan atau nilai moneternya (Dunn, 2003).Efektifitas mengandung kata kerja efektif yang berarti terjadinya suatu hubungan sebab akibat atau efek yang dikehendaki dalam suatu perbuatan. Setiap pekerjaan yang dapat terjangkau secara efisien tentu saja pekerjaan itu berarti efektif dilihat dari sisi hasil, tujuan atau akibat yang dikehendaki dengan berbuat itu telah tercapai, bahkan secara maksimal (baik mutu maupun jumlahnya) sebaliknya dilihat dari segi usaha efek yang diharapkan juga telah berhasil dicapai bahkan dengan usaha-usaha yang maksimal. Setiap pekerjaan yang efektif belum tentu efisien, karena hasil mungkin dicapai dengan penghamburan material, juga berupa pikiran, tenaga, waktu maupun benda lainnya.

Efektivitas menggambarkan tingkat pencapaian hasil program dengan target yang ditetapkan. Secara sederhana efektivitas merupakan perbandingan outcome dengan output yang dihasilkan (Mardiasmo, 2009). Pendapat yang sama diungkapkan oleh Emerson, efektivitas adalah pengukuran dalam arti pencapaian sasaran atau tujuan yang ditentukan sebelumnya (Nasila, 2014). Jadi efektivitas adalah suatu kegiatan diukur dari besar kecilnya persesuaian antara tujuan yang ingin dicapai dengan hasilnya. efektifivitas adalah kemampuan dari setiap perangkat kerja manusia dapat melahirkan suatu hasil yang maksimal yang digunakan sesuai dengan tujuan yang diharapkan (Cahyono, 2003).

Suatu kebijakan dikatakan efektif jika kebijakan tersebut berhasil dilaksanakan dengan baik. Bila sasaran atau tujuan telah tercapai sesuai dengan yang direncanakan sebelumnya dapat disebut efektif. efektivitas merupakan pencapaian tujuan kebijakan melalui pemanfaatan sumber daya yang dimiliki secara efisien, ditinjau dari sisi masukan (input), proses, maupun keluaran (output). Dalam hal ini yang dimaksud sumber daya meliputi ketersediaan personil, sarana dan prasarana serta metode dan model yang digunakan. Suatu kegiatan dikatakan efisien apabila dikerjakan dengan benar dan sesuai dengan prosedur sedangkan dikatakan efektif bila kegiatan tersebut dilaksanakan dengan benar dan memberikan hasil yang bermanfaat.

Dalam pengukuran suatu kebijakan ada beberapa kendala yang dihadapi, salah satunya adalah faktor dari keluaran, kebanyakan berupa keluaran yang tak berwujud (inatangible output) yang tidak mudah untuk dikuantifikasi, selain itu keluaran (output) dari program tersebut seringkali tidak dapat diketahui dalam jangka pendek, akan tetapi dalam jangka panjang setelah program dijalankan, sehingga ukuran efektivitas biasanya dinyatakan secara kualitatif (berdasarkan pada mutu) dalam 
bentuk pernyataan saja (judgement), artinya apabila mutu yang dihasilkan baik, maka efektivitasnya baik pula.

Efektivitas dalam segi alat peraga kampanye dapat dikatakan efektif jika tujuan dari alat peraga kampanye sudah tercapai. Seperti pengertian dari efektivitas yang dipaparkan oleh Etzoni, 1964 (Simamora, 2008) bahwa efektivitas adalah tingkat keberhasilan dalam mencapai tujuan atau sasaran. Prokopenko, 1987 menegaskan bahwa efektivitas merupakan suatu konsep yang sangat penting, karena mampu memberikan gambaran mengenai keberhasilan seseorang dalam mencapai sasaran atau tujuan (Simamora, 2008). Maka pengertian dari efektivitas tersebut sesuai dengan maksud dari penulisan ini dimana dalam penulisan ini ingin mengetahui apakah tercapai atau tidaknya tujuan dari fasilitasi Alat Peraga Kampanye yaitu prinsip kesetaraan antar peserta kampanye dan ketertiban pemasangan alat peraga kampanye.

\section{Metode}

Penelitian ini menggunakan pendekatan kualitatif dengan metode studi kasus. Dalam penulisan ini menggunakan jenis penulisan studi kasus instrumen tunggal (single instrumental case study). Penelitian studi kasus instrumental tunggal adalah penelitian studi kasus yang dilakukan dengan menggunakan sebuah kasus untuk menggambarkan suatu isu atau perhatian. Pada penelitian ini, penelitinya memperhatikan dan mengkaji suatu isu yang menarik perhatiannya, dan menggunakan sebuah kasus sebagai sarana (instrumen) untuk menggambarkannya secara terperinci (Creswell, 2007). Dalam penelitian ini peneliti mencoba untuk mengkaji suatu isu yaitu banyaknya APK yang difasilitasi KPU yang tidak terpasang dan bahkan ada beberapa peserta pemilu yang tidak memanfaatkan fasilitasi APK ini dan mengangkat kasus yang ada pada kampanye pemilu tahun 2019 di Kota Bukittinggi. Permasalahan tersebut juga dikaitkan dengan penggunaan sistem Pemilu proporsional terbuka dan mencoba menggunakan kasus yang terjadi pada Pemilu Tahun 2019 di Kota Bukittinggi sebagai sarana (instrumen) untuk menggambarkan permasalahan tersebut secara terperinci.

Penulisan ini akan mempelajari peristiwa dan aktifitas selama kegiatan fasilitasi APK itu berlangsung. Sehingga dirasakan sangat penting untuk mendalami dinamika persoalan kebijakan fasilitasi Alat Peraga Kampanye oleh KPU yang disampaikan oleh informan, kemudian kata-kata tersebut dianalisis dan digambarkan dalam bentuk hasil penulisan. Teknik pengumpulan data yang dilakukan adalah berupa wawancara kepada beberapa pihak yang berkompeten yaitu Pihak KPU Kota Bukittinggi sebagai pelaksana regulasi kebijakan fasilitasi Alat Peraga Kampanye, Bawaslu Kota Bukittinggi yang salah satu tugasnya adalah sebagai pengawas dari kebijakan yang dikeluarkan oleh KPU, peserta Pemilu yang menerima fasilitasi APK oleh KPU yang terdiri dari partai politik dan Tim Sukses Capres dan Cawapres tingkat Kota Bukittinggi. Teknik pengumpulan data lainnya yaitu berupa pengumpulan Dokumentasi dan Observasi terkait dengan fasilitasi APK di Kota Bukittinggi.

\section{Hasil dan Pembahasan}

\section{Kendala Implementasi Kebijakan Fasilitasi APK}

Tahapan Implementasi atau biasa disebut tahapan pelaksanaan merupakan tahapan yang paling krusial dalam suatu kegiatan dimana menentukan keberhasilan suatu program. Oleh karena 
itu, dalam bagian ini penulis akan mencoba menggambarkan proses implementasi kebijakan fasilitasi APK yang dilakukan oleh KPU Kota Bukittinggi pada pemilu tahun 2019 dengan mengaitkan dengan model implementasi program Korten. Menurut Korten, keberhasilan implementasi program harus memiliki tiga elemen kesesuaian. Ketiga elemen tersebut saling berkaitan satu sama lain sehingga ketika terdapat salah satu elemen yang tidak sejalan dengan optimal maka akan mempengaruhi elemen yang lain, ketiga elemen itu adalah keseuaian program, kesesuaian pelaksanaan program dan kesesuian program dengan kelompok sasaran.

\section{Kesesuaian Program}

Keselarasan antara program dan kebutuhan kelompok sasaran mutlak diperlukan. Apabila program tidak sesuai dengan kebutuhan kelompok sasaran, maka dapat dipastikan bahwa hasil program tidak akan memberikan output yang sesuai dengan yang diinginkan. Tujuan awal KPU melakukan fasilitasi APK ini adalah agar semua peserta pemilu mempunyai kesempatan yang sama dalam berkampanye. Bertolak kepada pengalaman pemilu sebelumnya dimana peserta pemilu yang mempunyai basis dana yang besar akan berusaha mencetak alat peraga sebanyak-banyaknya. Berbeda dengan peserta pemilu yang baru muncul mereka terkendala dalam kampanye karena dana yang terbatas. Akan tetapi, faktanya pada waktu penerapan kebijakan fasilitasi APK ini tujuan dari fasilitasi APK ini tidak sampai. Hal itu disebabkan oleh KPU setelah melakukan fasilitasi APK kepada peserta pemilu juga memberi peluang kepada peserta pemilu untuk melakukan pencetakan mandiri meskipun dalam jumlah terbatas, seperti terdapat pada keputusan KPU No. 1096/PL.01.5-Kpt/06/KPU/IX/2018 mengenai petunjuk teknis metode kampanye pada pemilu tahun 2019 pada poin (12) Penambahan Alat Peraga Kampanye oleh Peserta Pemilu huruf (f) Desain dan materi penambahan APK untuk Pemilu DPR, DPRD Provinsi dan DPRD Kabupaten/Kota selain ketentuan sebagaimana dimaksud pada angka 8 huruf b.2) dapat memuat foto Calon Anggota DPR, DPRD Provinsi dan/atau DPRD Kabupaten/Kota di daerah pemilihan yang bersangkutan. Pemberian peluang dari KPU kepada Caleg dalam mencetak APK secara mandiri mengakibatkan fungsi fasilitasi APK yaitu persamaan hak dalam kampanye menjadi tidak signifikan lagi apalagi dikaitkan dengan sanksi yang diberikan tidak tegas

Pemberian peluang bagi peserta pemilu dalam mencetak APK secara mandiri akan menjadi bias aturan dan tujuan dari penertiban alat kampanye tersebut mejadi hilang Karena di satu sisi KPU telah memfasilitasi APK disisi lain Peserta Pemilu juga diberi peluang untuk mencetak APK sehingga berakibat kepada timbulnya konflik aturan pada saat penerapan aturan. Satu sisi KPU telah memfasilitasi APK bagi peserta pemilu disisi lain caleg juga diberi peluang dalam mencetak APK mandiri. Sehingga di lapangan akan dapat kita lihat terlalu banyaknya alat peraga kampanye yang bertebaran di jalan menjadikan tatanan estetika kota menjadi semrawut, karena hampir semua partai tidak mengindahkan adanya peraturan dari KPU (Pinem, 2104). Dengan demikian, akhirnya membuat bingung para pemilih karena banyaknya alat peraga kampanye yang berserakan disekitarnya. Pemasangan alat peraga kampanye yang berlebihan juga dapat berdampak kepada kinerja penyelenggara Pemilu.

David Easton menjelaskan bahwa dalam sistem politik dibutuhkan keteraturan sehingga mencapai tujuan politik yang diinginkan, keteraturan ini terkait seberapa besar kemampuan subyek penyelenggara tersebut secara sosiologis (keadaannya) dan psikologis (rasa mampu) (Budiardjo, 
2015). Beberapa permasalahan diatas dapat diambil benang merahnya bahwa aturan fasilitasi APK yang dibuat KPU belum memenuhi kesesuaian program karena antara aturan satu dengan aturan lain tidak sejalan seperti ketika tujuan awal fasilitasi APK agar semua peserta pemilu mempunyai kesempatan yang sama dalam berkampanye tidak sejalan dengan aturan lainnya yaitu pemberian peluang kepada peserta pemilu untuk melakukan pencetakan APK mandiri, sehingga peserta pemilu yang mempunyai sumber dana yang besar masih akan terus berkampanye secara masif berbeda dengan peserta pemilu yang memiliku dana minim tentu saja mereka akan terbatas dalam melakukan kampanye.

\section{Kesesuaian Pelaksanaan Program}

Pada bagian ini Korten menekankan kesesuaian antara program dengan organisasi pelaksana. Kesesuaian antara program yang diberikan dengan kemampuan pelaksana harus dapat dilakukan dengan baik. Jika organisasi pelaksana tidak memiliki kemampuan melaksanakan tugas yang diberikan, maka organisasi pelaksana tidak dapat menyampaikan manfaat program yang telah ditentukan. Sehingga diperlukan sikap implementor yang memiliki kemampuan untuk melaksanakan tugas dengan baik.

Untuk Keseluruhan tahapan proses fasilitasi APK yang dilakukan oleh KPU Kota Bukittinggi peserta pemilu dan Bawaslu Kota Bukittinggi pada umumnya menganggap bahwa KPU sudah melaksanakan tugasnya dengan baik dinilai dari fungsi dan wewenang karena KPU Kota Bukittinggi bekerja sesuai dengan arahan yang berjenjang mulai dari KPU Provinsi sampai ke KPU RI. Seperti hasil wawancara yan dilakukan terhadap Sekretaris PKS Kota Bukittinggi bahwa sebenarnya dari segi profesional KPU Kota Bukittinggi sudah bekerja sesuai instruksi yang ada dari atas, jadi sudah terstruktur sesuai dengan agenda KPU itu sendiri. Dari segi pelayanan, sosialisasi fasilitasi APK memang difasilitasi oleh KPU, karana KPU sudah menyediakan layanan itu selama kampanye.

Data yang sama didapat dari hasil wawancara terhadap KPU Kota Bukittinggi yang menyampaikan bahwa mereka sudah bekerja sesuai dengan kewenangan mereka. Indikator dari kinerja KPU Kota Bukittinggi itu dapat dilihat dari tidak adanya tuntutan dari peserta pemilu ataupun Bawaslu mengenai fasilitasi APK ini. Tekait dengan adanya perbedaan pandangan antara partai dengan KPU mengenai PKPU No. 23 Tahun 2018 pasal 23 ayat 2 yang berbunyi KPU dapat memfasilitasi APK peserta pemilu salah satunya pemasangan alat peraga kampanye berbeda dengan aturan Petunjuk teknis No. No.946/PP.08-SD/06/KPU/VIII/2018 bahwa KPU untuk fasilitasi APK hanya sampai pemasangan saja. Setelah melalui beberapa pertemuan peserta pemilu memahami bahwa KPU Kota Bukittinggi juga menginginkan pemasangan oleh KPU seperti Pilkada Tahun 2015 lalu, tetapi karena KPU Kota Bukittinggi hanya menjalankan aturan yang ada dari KPU RI maka fasilitasi APK untuk Pemilu Tahun 2019 hanya sampai pencetakan saja. Secara keseluruhan dapat disimpulkan bahwa kinerja KPU Kota Bukittinggi dalam proses fasilitasi APK ini sudah baik itu terlihat dari tidak adanya tuntutan atau gugutan yang bersifat masif terhadap fungsi fasilitasi APK ini.

Dari beberapa pernyataan diatas bahwa KPU Kota Bukittinggi sebagai organisasi pelaksana dengan program yang dijalankan sudah berjalan profesional sesuai wewenang dan tugas mereka ditingkat KPU Kota Bukittinggi. Salah satu indikator dari kesesuaian tersebut adalah tidak 
adanya tuntutan dan teguran baik dari peserta pemilu ataupun Bawaslu mengenai fasilitasi APK ditingkat Kota Bukittinggi.

\section{Kesesuaian Program dengan Kelompok Sasaran}

Diyakini oleh KPU bahwa fungsi APK lebih dari sekedar memberi informasi tetapi juga dirancang untuk mempersuasi orang yang melihatnya. Untuk itu APK didesain untuk mempengaruhi masyarakat dalam menentukan perwakilan aspirasinya. Dua tipe APK yang difasilitasi KPU Kota Bukittinggi adalah spanduk dan baliho.

Secara umum, peserta pemilu merasa kecewa dengan kebijakan fasilitasi APK oleh KPU. Terdapat beberapa alasan. Pertama, persepsi kebutuhan peserta pemilu tidak sesuai dengan persepsi kebutuhan APK oleh KPU. Sesungguhnya, ukuran dan desain APK sudah memiliki aturan baku dari KPU dan berlaku untuk seluruh Indonesia. Konten APK berdasarkan ketentuan KPU hanya memuat visi misi partai disertai foto dari pengurus partai. Pengurus partai seperti ketua, sekretaris, dan bendahara disertai nomor urut partai. Sehingga, konten APK yang diberikan oleh peserta pemilu dan tidak sesuai standar tersebut, tidak akan diterima. Sehingga berdasarkan hasil pengamatan penulis, hanya spanduk yang terlihat terpasang tetapi tidak berada pada zona kampanye yang telah ditentukan seperti terlihat pada gambar 2 bahwa peserta pemilu memasang APK yang difasilitasi KPU pada warung atau kedai yang tidak merupakan zona pemasangan APK. Peserta pemilu merasa fungsi persuasi yang ada dalam spanduk dan baliho yang difasilitasi KPU tidak dapat dimaksimalkan oleh peserta pemilu. Fenomena ini sungguh sangat disayangkan karena anggaran negara sudah banyak terpakai untuk fasilitasi APK ini.

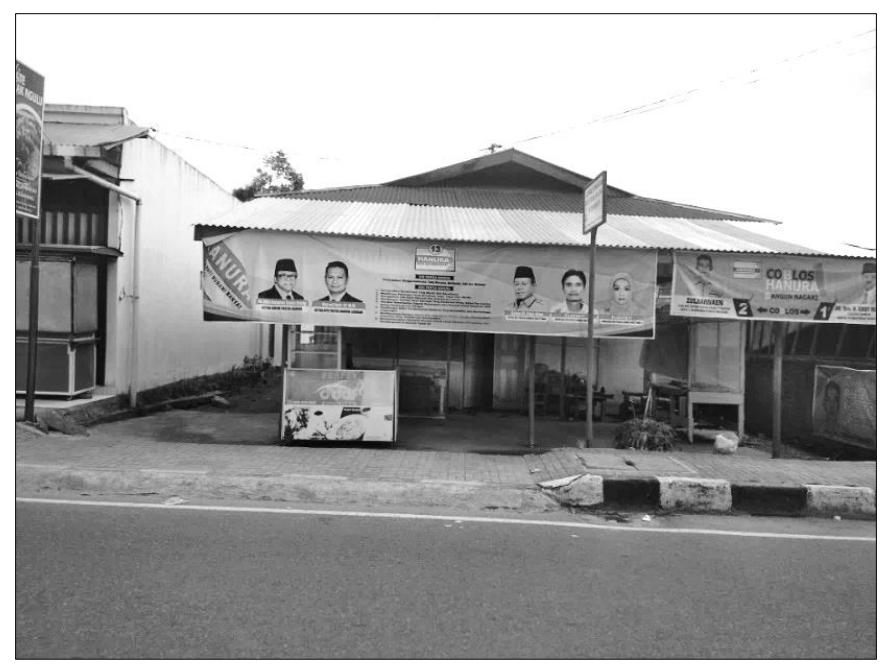

Gambar 2. Pemasangan APK yang difasilitasi KPU tidak pada zona yang telah ditentukan

Kedua, adanya faktor ketidakadilan dalam implementasi fasilitasi APK. Kebijakan fasilitasi APK tidak mengakomodir foto calon legislatif (caleg) sehingga banyak caleg yang protes dan menimbulkan dilema bagi pengurus partai. Berdasarkan hasil temuan, partai PDI Perjuangan di Bukittinggi memutuskan untuk tidak memasang fasilitas APK dari KPU untuk menghindari terjadinya konflik antara pegurus partai yang juga ikut dalam mencalonkan diri dalam pemilu dengan caleg PDI Perjuangan. Hasil wawancara terhadap pengurus PDIP Kota Bukittinggi yang 
menyatakan bahwa PDIP Kota Bukittinggi tidak menggunakan fasilitasi dan menyatakan dengan surat pernyataan tertulis bermaterai. Alasannya utamanya alat peraga itu kan hanya mencamtumkan foto pengurus saja, bagaimana dengan caleg lain yang tidak sebagai pengurus partai. Banyak caleg yang protes kenapa hanya pengurus partai saja yang masuk. Jadi agar supaya tidak terjadi saling curiga antara pengurus dan caleg, maka PDIP Kota Bukittinggi memutuskan untuk tidak ikut serta dalam fasilitasi APK di Kota Bukittinggi.

Ketiga, terdapat perbedaan aturan fasilitasi APK pada Pemilihan Kepala Daerah (pemilukada) 2018 dengan tahun 2019. Pemilukada tahun 2018 didasarkan pada Peraturan KPU No.4 Tahun 2017 yang memfasilitasi APK mulai dari pencetakan sampai dengan pemasangan di tempat. Sementara, pada Pemilu 2019 khusus untuk Kabupaten/Kota sesuai Petunjuk Teknis No. 946/PP.08-SD/06/KPU/VIII/2018 Tentang petunjuk Teknis Fasilitasi APK bagi Peserta Pemilu jumlah APK yang difasilitasi KPU khususnya untuk kabupaten kota antara lain untuk tim pemenangan capres dan cawapres mendapatkan maksimal 10 buah baliho dan 16 buah spanduk, untuk partai politik mendapatkan maksimal 10 buah baliho dan 10 buah spanduk sedangkan calon perseorangan DPD hanya mendapatkan spanduk sebanyak 10 buah untuk tingkat kabupaten/kota. Setelah dilakukan pencetakan maka dilakukanlah penyerahan APK kepada Peserta Pemilu. Sehingga, pemilukada tahun 2018 pemasangan fasilitas APK lebih terlihat teratur dan tertib.

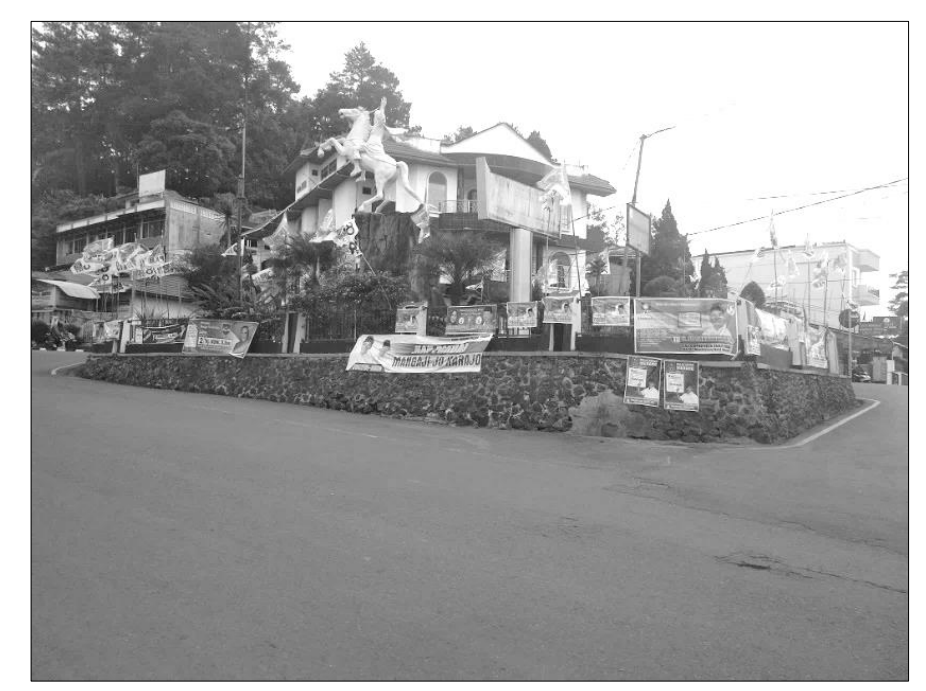

Gambar 3. Lokasi Pemasangan APK yang tidak Sesuai Aturan

Berdasarkan pengamatan penulis, implementasi dari peraturan fasilitasi APK tahun 2019 di Kota Bukittinggi belum optimal. Pasca KPU Kota Bukittinggi mengeluarkan Surat Keputusan No. 36/HK.03.1-Kpt/1375/KPU-Kot/IV/2018 tanggal 21 September 2018 tentang Lokasi Pemasangan Alat Peraga Kampanye Pemilihan Umum Tahun 2019 di Kota Bukittinggi, di lokasi pemasangan hampir tidak ada spanduk dan baliho yang difasilitasi tersebut. Berdasarkan hasil observasi selama massa kampanye pemilu tahun 2019, penulis hanya menemukan foto-foto Caleg yang berserakan dimana-dimana sehingga mengganggu keindahan dan estetika kota dan hampir semua fasilitasi APK yang dilakukan KPU tidak terpasang pada zona yang telah ditentukan. Contoh kasusnya adalah berdasarkan SK KPU Kota Bukittinggi No. 36/HK.03.1Kpt/1375/KPU-Kot/IV/2018 mengenai lokasi pemasangan APK Pemilu tahun 2019, Salah 
satunya di Kelurahan Puhun Tembok Kota Bukittinggi tepatnya di persimpangan tembok dimana lokasi tersebut dilarang sebagai pemasangan APK, faktanya di lokasi tersebut masih banyak ditemukan APK caleg yang dipasang tidak teratur seperti terlihat pada gambar 3.

Permasalahan masih banyaknya APK yang dipasang tidak beraturan pada kampanye pemilu tahun 2019 telah mengkonfirmasi kembali penelitian (Yulianto, 2014) bahwa karena jumlahnya yang banyak, isi pesan dan tampilan alat peraga kampanye cenderung monoton. Bukannya dipandang sebagai alat pemberi informasi dari kandidat kepada pemilih tetapi akan membuat risih karena mengotori lingkungan.

Terkait dengan APK yang difasilitasi oleh KPU banyak yang tidak dipasang pada zona yang telah ditentukan oleh peserta pemilu pada umumnya karena masalah biaya dikeluhkan oleh hampir seluruh peserta pemilu. Mereka mengganggap fasilitasi KPU bukan hanya sampai pencetakan saja tetapi memfasilitasi semuanya dari mulai pencetakan, pemasangan dan pemeliharaan itu mungkin lebih efektif. Seperti yang disampaikan oleh Sekretaris partai Golkar Kota Bukittinggi bahwa KPU hanya memfasilitasi pencetakan alat peraga dan menentuan titik pemasangan saja. sementara untuk mangerjakan merangka, memasang dan merawat APK diserahkan kepada partai. Jadi lebih besar biaya merangka dibandingkan biaya cetak spanduk itu sendiri. Setelah itu dalam proses menempatkannya ada juga biaya untuk pemuda sekitar pemasangan. Kalau tidak baliho kami akan hilang malam, Jadi tidak maksimal. Sementara biaya yang disediakan pemerintah untuk KPU lumayan besar. Mungkin kalau KPU yang memasangkan masyarakat atau pemuda tidak akan meminta biaya tambahan.

Berdasarkan teori Korten, implementasi kebijakan fasilitasi APK dari KPU dalam Pemilu tahun 2019 belum maksimal. Meskipun KPU selaku pelaksana sudah maksimal dalam menjalankan tugasnya, akan tetapi terdapat ketidakkesesuain program yang dibuat dengan kebutuhan kelompok sasaran program yang menjadi penghambat implementasi kebijakan. Padahal, keberhasilan sebuah program tergantung kepada ketepatan sasaran program yang ditentukan oleh organisasi pelaksana. Dengan demikian, tujuan program dapat bermanfaat bagi kelompok sasaran. Jika tujuan yang telah ditetapkan dari awal tidak dapat tercapai maka otomatis program itu tidak akan berhasil dan kelompok sasaran tidak memperoleh manfaat dari program tersebut.

\section{Efektifitas Fasilitasi APK}

Sesuai dengan definisi efektifitas yang dikemukan oleh etzoni bahwa efektivitas adalah tingkat keberhasilan dalam mencapai tujuan atau sasaran, yaitu sejalannya input yang digunakan dengan output yang ingin dicapai. Dikaitkan dengan permasalahan fasilitasi APK yang dilakukan KPU yaitu masih banyak APK yang tidak terpasang pada zona yang ditentukan sehingga penting diukur sejauh mana efektifitas fasilitasi APK ini.

KPU memfasilitasi APK bagi peserta pemilu sedangkan peserta pemilu yang dimaksud peraturan KPU No. 23 tahun 2018 tentang kampanye pemilu bahwa peserta pemilu adalah partai politik, pasangan calon presiden dan wakil presiden dan juga calon anggota DPD sedangkan sistem Pemilu yang dianut oleh Indonesia saat sekarang ini yaitu proporsional terbuka (open list) yang memberikan kedaulatan penuh kepada rakyat dalam memilih wakil mereka di parlemen. Sistem proporsional terbuka mengakibatkan terjadinya persaingan yang kurang sehat (politik destruktif) antar caleg dalam satu partai, kontestasi sesama caleg internal satu partai dan bukan dengan partai 
lain (Budiono, 2017).Dikaitkan dengan fasilitasi APK yang dilakukan oleh KPU dimana fokus dari fasilitasi tersebut adalah kepada Partai politik untuk berkampanye sedangkan sistem pemilu proporsional terbuka yang lebih mengutamakan caleg dalam berkampanye, sehingga kedua hal tersebut menjadi bertentangan dan tidak sejalan dan mengakibatkan fasilitasi APK tersebut menjadi tidak relevan.

Sistem pemilu proporsional terbuka dengan penentuan calon terpilih berdasarkan suara terbanyak ini banyak kalangan berpendapat akan menghasilkan sistem pemilu liberal yang menitikberatkan pada kekuatan individu dalam berkampanye. Partai politik hanya dijadikan sebagai alat atau kendaraan politik untuk mencapai tujuan terpilihnya calon tersebut.

Sebaliknya kebijakan fasilitasi APK yang baru dilakukan KPU pada pemilu tahun 2019 berdasarkan PKPU No.23 Tahun 2018 tentang kampanye pemilihan umum yaitu KPU dapat memfasilitasi pemasangan Alat peraga bagi peserta pemilu ditempat umum sedangkan defenisi peserta pemilu menurut peraturan tersebut adalah Partai Politik untuk Pemilu anggota DPR, anggota DPRD provinsi, anggota DPRD kabupaten/kota, perseorangan untuk Pemilu anggota DPD, dan Pasangan Calon yang diusulkan oleh Partai Politik atau Gabungan Partai Politik untuk Pemilihan Umum Presiden dan Wakil Presiden. Dapat dilihat bahwa sistem pemilu proporsional terbuka yang berbasiskan caleg dalam berkampanye dengan kebijakan fasilitasi APK yang berbasiskan partai politik dalam berkampanye itu tidak sejalan sehingga berakibat kepada tidak maksimalnya fungsi fasilitasi APK yang dilakukan oleh KPU.

Tidak sejalannya antara sistem pemilu proporsional terbuka dengan kebijakan fasilitasi APK akan menyebabkan beberapa dampak dalam proses kampanye yang dilakukan pada saat pemilu 2019 antara lain: 1) Persaingan Antar Caleg Dalam Berkampanye Tidak Kompetitif. KPU setelah melakukan fasilitasi APK kepada peserta pemilu juga memberi peluang kepada peserta pemilu untuk melakukan pencetakan mandiri meskipun dalam jumlah terbatas, seperti terdapat pada keputusan KPU No.1096/PL.01.5-Kpt/06/KPU/IX/2018. Pengaruh dari pemberian peluang bagi caleg dalam mencetak APK menjadikan persaingan antar caleg dalam berkampanye semakin meruncing, apalagi dikaitkan dengan penggunakan sistem suara terbanyak. Penggunaan sistem pemilu proporsional terbuka mengakibatkan persaingan antar caleg bukan hanya antar caleg dengan partai berbeda tetapi justru persaingan itu terjadi dalam internal partai itu sendiri.

Seharusnya KPU sebagai penyelenggara pemilu dapat meredam persaingan antar caleg tersebut dengan melaksanakan kebijakan fasilitasi APK ini lebih akomodatif yaitu mengakomodir pemasangan foto caleg dalam APK yang difasilitasi KPU dan menerapkan aturan kampanye bersama yang dikoordinasi oleh partai dengan menerapkan sanksi yang tegas mungkin pelanggaran kampanye bisa diminimalisir. Akibat dari awal pelaksanaan aturan fasilitasi APK yang tidak tepat tersebut mengakibatkan fasilitasi APK ini menjadi tidak efektif. 2) Fasilitasi APK yang Diadakan KPU Banyak Tidak Terpakai. Tujuan awal KPU melakukan fasilitasi APK ini adalah agar semua peserta pemilu mempunyai kesempatan yang sama dalam berkampanye. Bertolak kepada pengalaman pemilu sebelumnya dimana peserta pemilu yang mempunyai basis dana yang besar akan berusaha mencetak alat peraga sebanyak-banyaknya. Berbeda dengan peserta pemilu yang baru muncul mereka terkendala dalam kampanye karena dana yang terbatas. Akan tetapi, faktanya pada waktu penerapan kebijakan fasilitasi APK ini tujuan dari fasilitasi APK ini tidak sampai apalagi jika dikaitkan dengan sistem pemilu proporsional terbuka yang dipakai di Indonesia saat ini. 
APK yang difasilitasi KPU dikarenakan dalam sistem pemilu proporsioal terbuka seharusnya caleg yang harus lebih difasilitasi dalam berkampanye bukan partai, juga sesuai dengan yang disampaikan oleh partai politik salah satunya PKS yang menjelaskan bahwa dengan memakai sistem pemilu proporsional terbuka maka figur dan keterkenalan caleg lebih utama disampaikan kepada masyarakat dalam kegiatan kampanye bukan hanya partai.

Pada akhirnya dapat diambil benang merahnya bahwa efektifitas fasilitasi APK oleh KPU kota Bukittinggi belum berjalan maksimal dihubungkan dengan teori efektifitas Etzoni bahwa sebuah program bisa dikatakan efektif jika berhasil dalam mencapai tujuan atau sasaran yang telah ditentukan. Dimana Fasilitasi APK yang dilakukan oleh KPU bertujuan untuk membantu partai politik dalam berkampanye sedangkan sistem pemilu proporsional terbuka yang lebih mengutamakan caleg dalam berkampanye. Mengakibatkan kedua sistem tersebut menjadi tidak sejalan dan output dari penggabungan dua kebijakan tersebut tidak tercapai.

\section{Kesimpulan}

Hasil penelitian menunjukkan bahwa kebijakan fasilitasi APK yang dilakukan oleh KPU Kota Bukittinggi belum maksmimal dilakukan pada tahap implementasi. Indikasi tersebut dapat dilihat dari tidak memenuhi tiga elemen kesesuaian implementasi yang disampaikan oleh Korten. Meskipun Pelaksana program yaitu KPU sudah maksimal dalam menjalankan tugasnya, akan tetapi adanya ketidakkesesuain program yang dibuat dengan kebutuhan kelompok sasaran program menjadi penghambat implementasi kebijakan ini.

Fenomena itu dapat dilihat dengan banyaknya partai yang tidak memasang APK bahkan ada peserta pemilu yang tidak memanfaatkan fasilitasi tersebut. Padahal KPU Kota Bukittinggi sudah berusaha maksimal dalam memfasilitasi APK ini, seperti telah memperpanjang waktu penyerahan desain APK dan juga merevisi tentang zona pemasangan APK dengan cara memperbanyak zona atau daerah yang telah ditetapkan sebelumnya.

Banyaknya fasilitasi APK dari KPU yang tidak terpasang dikaitkan dengan masalah besarnya biaya yang dikeluhkan oleh peserta pemilu pada saat pemasangan APK pada umumnya dikeluhkan oleh hampir peserta pemilu, mereka mengganggap KPU seharusnya bukan hanya sampai pencetakan saja tetapi juga memfasilitasi semuanya dari mulai pencetakan, pemasangan dan pemeliharaan itu mungkin lebih efektif. Peserta pemilu juga mengeluhkan pada saat proses pemasangan, faktor ukuran dan isi konten dari APK yang difasilitasi sudah ditentukan oleh KPU hanya berisi visi misi partai disertai foto dari pengurus dalam hal ini ketua, sekretaris dan bendahara disertai nomor urut partai jugasangat dikeluhkan oleh peserta pemilu.

Efektifitas fasilitasi APK pada Pemilu tahun 2019 di Kota Bukittinggi belum mencapai tujuan yang diinginkan. Dimana Fasilitasi APK yang dilakukan oleh KPU bertujuan untuk membantu partai politik dalam berkampanye sedangkan sistem pemilu proporsional terbuka yang lebih mengutamakan caleg dalam berkampanye itu tidak sejalan sehingga berakibat kepada tidak maksimalnya fungsi fasilitasi APK yang dilakukan oleh KPU Kota Bukittinggi. Tidak sejalannya antara sistem pemilu proporsional terbuka dengan kebijakan fasilitasi APK akan menyebabkan beberapa dampak dalam proses kampanye antara lain persaingan antar caleg dalam berkampanye menjadi tidak kompetitif dan juga fasilitasi APK yang diadakan oleh KPU menjadi banyak yang tidak terpakai. 
This is an open access article

under the CC-BY-SA license

\section{Referensi}

Akib, H., \& Tarigan, A. (2008). Artikulasi Konsep Implementasi Kebijakan: Perspektif, Model dan Kriteria Pengukurannya. Jurnal.

Budiardjo, M. (2015). Dasar-Dasar Ilmu Politik. Jakarta: Gramedia.

Budiono. (2017). Menggagas Sistem Pemilihan Umum yang Sesuai dengan Sistem Demokrasi Indonesia. Jurnal Ilmiah Dunia Hukum, 33-44.

Cahyono. (2003). Manajemen Industri Kecil. Yogyakarta: Liberty.

Creswell, J. W. (2007). Qualitative Inquiry \& Research Design. Sage Publications, Inc. https://doi.org/10.1111/1467-9299.00177

Dunn, W. N. (2003). Pengantar Analisis Kebijakan Publik. Terjemahan Samodra Wibawa. Yogyakarta: Gadjah Mada University Press.

Pemerintah Indonesia . (2017). Undang-undang No. 7 Tahun 2017 Tentang Pemilihan Umum. Diunduh pada https://www.hukumonline.com/pusatdata/detail/lt59ba5511ab93b/undang-undangnomor-7-tahun-2017

Korten, D. C. (1980). Community Organization and Rural Development: A Learning Process Approach. Public Administration Review. https://doi.org/10.2307/3110204

KPU. (2018). Peraturan KPU No.23 Tahun 2018 Tentang Kampanye Pemilihan Umum Tahun 2019. Diunduh Pada http://perludem.org/2018/07/31/pkpu-no-23-tahun-2018tentang-kampanye-pemilihan-umum/

Kurniawan, R. C. (2009). Kampanye Politik : Idealitas dan Tantangan. Jurnal Ilmu Sosial Dan Ilmu Politik, Volume 12,(ISSN 1410-4946), 257-390. https://doi.org/https://doi.org/10.22146/jsp.10973

Mardiasmo. (2009). Akuntansi Sektor Publik. Yogyakarta: Andi.

Nasila, J. W. (2014). Efektivitas Program Daerah Pemeberdayaan Masyarakat (PDPM) Studi Tentang Penanggulangan Kemiskinan di Kelurahan Mambaro Kota Palu. Jurnal ACADEMICA Fisip Untad, 06, 1253-1264.

Pinem, K. (2104). Kamuflase Politik Dalam Alat Peraga Kampanye. Jurnal Pendidikan Ilmu-Imu Sosial, 6(2), 22-26.

Rogers, E. M., \& Storey, J. D. (1987). Communication campaigns. Handbook of Communication Science. https://doi.org/10.4135/9781412982818

Sabatier, P., \& Mazmanian, D. (1980). THE IMPLEMENTATION OF PUBLIC POLICY: A FRAMEWORK OF ANALYSIS. Policy Studies Journal. https://doi.org/10.1111/j.15410072.1980.tb01266.x

Simamora, H. (2008). Manajemen Sumber Daya Manusia. Yogyakarta: STIE YKPN.

Surbakti, R. (1992). Memahami Ilmu Politik. Jakarta: Grasindo.

Sutarini, I. A. (2019). Pengukuran Efektivitas Penggunaan Media Baliho Pada Pemilihan Umum 2019 Terhadap Generasi Milenial. Seminar Nasional Desain Dan Arsitektur, 2, 237-241. Diunduh pada https://eprosiding.std-bali.ac.id/index.php/senada/article/view/217

Yulianto, M. (2014). Evaluasi Alat Peraga Kampanye Pemilihan Umum Di Era Demokrasi Elektoral. Semarang: Jurnal ilmu Sosial Vol.13 No.1.

\section{Wawancara}

Komisioner KPU Kota Bukittinggi, (2019). Bukittinggi, Jumat, 25 Oktober 2019

Anonim, pengurus DPC Gerindra Kota Bukittinggi. (2019). Bukittinggi, Kamis 11 November 2019.

Anonim, pengurus DPD PartaiGolkar Kota Bukittinggi. (2019). Bukittinggi, Jumat 22 November 2019. 
This is an open access article under the CC-BY-SA license

Anonim, pengurus DPD PKS Kota Bukittinggi. (2019). Bukittinggi, Kamis, 5 Desember 2019 Anonim, pengurus DPD Nasdem Kota Bukittinggi. (2019). Bukittinggi, Jumat, 13 Desember 2019. 